Article

\title{
Cost of Urban Wastewater Treatment and Ecotaxes: Evidence from Municipalities in Southern Europe
}

\author{
Encarnación Moral Pajares ${ }^{1}$, Leticia Gallego Valero ${ }^{1, *}$ and Isabel María Román Sánchez ${ }^{2,3}$ (i) \\ 1 Department of Economy, University of Jaén, 23071 Jaén, Spain; emoral@ujaen.es \\ 2 Department of Economy and Business, University of Almería, 04120 Almería, Spain; iroman@ual.es \\ 3 Solar Energy Research Centre (CIESOL), Joint Centre University of Almería-CIEMAT, 04120 Almería, Spain \\ * Correspondence: lgallego@ujaen.es; Tel.: +34-651-888-733
}

Received: 25 December 2018; Accepted: 25 February 2019; Published: 27 February 2019

\begin{abstract}
The principle of cost recovery established by the Water Framework Directive underlines the need for tax rates, which can raise enough revenue to finance the cost of treatments applied to wastewater. The objective of this research is to gain an understanding the different types of charges related to urban wastewater treatment that can be levied by the authorities responsible for this service. This paper also aims to determine whether these taxes contribute to guaranteeing the economic feasibility of the wastewater treatment plants. The proposed methodological approach is applied to 18 municipalities of a province in southern Europe in 2017. The results confirm that in most of these cases, the taxes levied do not guarantee adequate tax revenues to cover the running, maintenance and investment costs of municipal wastewater treatment plants. This situation leads to a lack of financial self-sufficiency in the wastewater management service, meaning that the imbalance between income and expenditure has to be covered by government subsidies. The results of this study will help guide authorities around the world that are in charge of managing urban wastewater treatment services.
\end{abstract}

Keywords: wastewater treatment; reuse; cost; ecotaxes

\section{Introduction}

When humans use water they alter its properties by introducing substances that modify its quality. Vital human functions as well as their productive, commercial, sanitary and industrial activity result in a process of anthropogenic contamination [1,2]. In the European Union, the protection of water resources from the effects of effluent discharge is regulated through Directive 91/271/EEC on the collection, treatment and disposal of urban wastewater and wastewater from certain industrial sectors, later amended by Commission Directive 98/15/EC and the Water Framework Directive 2000/60/EC (WFD). This regulation states that all Member States must have effective models of wastewater treatment (WWT) and sanitation networks. Likewise, it requires that aqueous waste be sent to wastewater treatment plants (WWTPs) before being discharged into water bodies or being reused [3,4]. Article 9 of the WFD further stipulates that Member States should take into account the criterion of cost recovery in water-related services, in accordance with the polluter pays principle $[5,6]$.

In Spain, as in other EU countries [3,5], the local councils are responsible for the management of the urban WWT service. Specifically, art. 25.2c of the Local Government Regulatory Law assigns all matters relating to domestic drinking water supply and wastewater disposal and treatment under the jurisdiction of the municipalities. This Law, together with Law 8/1989, of 13 April, on Public Prices and Fees, allows local municipalities to establish ecotaxes directly linked to financing the WWT service. Very few studies to date have dealt with the financial sustainability of urban WWT services. Of those that have, it is worth highlighting the analysis by Gallego-Valero et al. [6], which uses an indirect method to analyse the financial sustainability of wastewater reclamation services for reuse; 
the WHO report that uses data from 94 countries [7], and a study by Fernández et al. [8] examining policies for economically efficient, environmentally sustainable and socially equitable drinking water and sewerage services. Most related research, however, focuses on analysing the operating costs of the different treatment systems applied: Molinos-Senante et al. [9] carry out a cost-benefit analysis with data from 13 WWTPs; Theregowda et al. [10] compares the costs of applying different tertiary treatments; Oh et al. [11] evaluates the costs and performance of an ozonation disinfection greywater treatment system; and De la Cruz et al. [12] estimates and compares operating costs incurred in the disposal of 22 selected micropollutants in an effluent from a municipal WWTP. Also noteworthy are those studies that, using nonparametric methods such as data envelopment analysis (DEA), have analysed the techno-economic efficiency of WWTPs, including Guerrini et al., Castellet et al. and Gómez et al. [13-15] which uses a double-bootstrap DEA model.

Wastewater management is expensive and poses problems regarding how to finance it. Setting tariffs to charge users for these services fulfils three basic functions [8]: (i) it frees up public resources that can be used for other purposes; (ii) it boosts effectiveness, by linking the revenues collected to the service provided; and (iii) it generates a clear signal to users about the real cost of the service, encouraging rational consumption. The objective of this research is twofold. In the first place, it is aimed at determining the different types of rates linked to WWT charged by the authorities responsible for the urban WWT service in a province in southern Europe. Secondly, the paper analyses whether these taxes generate sufficient revenue to cover the operating costs of municipal WWTPs, accounting for both the fixed and variable costs of the facilities, also referred to as operating and maintenance costs, and the investment and depreciation costs [6,10,16,17].

The proposed methodological approach is applied to 18 municipalities in the province of Jaén, in southern Europe, in 2017. The results of this study are intended to contribute to research on cost recovery and financial self-sufficiency in WWT and reclamation, a costly and capital-intensive activity. Moreover, the analysis carried out will produce objective findings that should help the authorities responsible for the urban WWT service to design financially-effective tax instruments [18-20]. A WWT rate that guarantees the financial self-sufficiency of urban WWT will allow compliance with the polluter pays principle established in the Water Framework Directive. Some authors question the validity of this principle, given that it plays down the role of other actions that States may implement in order to gradually reduce the pollution of water resources, as established in WFD art. 4 [21]. In this regard, they assert the effectiveness of other systems, such as the use of command-and-control instruments, which impose a legal limit on the amount of pollution that each polluter is allowed to emit [22], or the use of economic mechanisms, which work by creating incentives for individuals and companies to voluntarily change their behaviour and assume the costs of controlling and repairing the damage caused by their activities [23]. Many governments are currently facing the challenge of ensuring the economic feasibility of urban WWT services, and this study can be of use in that regard, by offering an easily replicable methodology. Lack of financing can lead to inadequate functioning of the facilities, deterioration or even closure, which has serious consequences for the natural environment.

\section{Materials and Methods}

To achieve the aforementioned objective, information from the Official Gazette of the Province of Jaén [24] was used. This gazette publishes the municipal ordinances that regulate the collection of municipal taxes related to WWT. This study focuses on the structure of the rates applied; leaving aside the underlying price regulation mechanisms that may determine those rates. Therefore, it is the resulting rates that are analysed, not the process of how they are set. In addition, primary information was derived from an empirical analysis carried out in order to estimate the average operating costs of a WWTP. The procedure followed has an eminently practical orientation, given the lack of classification and quantification in the costing systems applied by the public entities involved [25]. This study specifically focuses on WWT; it does not account for sewerage costs (operating, maintenance and investment in municipal sewer systems), which have been included in other studies [26]. 
The population under analysis, the procedure used to collect the primary data and the criteria considered in the analysis are described below.

\subsection{Population}

The population under study is made up of the municipalities in the province of Jaén in which the local administration collects an ecotax for urban WWT and has municipal WWT facilities that comply with art. 4 of Directive 91/271/EEC. This population was obtained from the Directory of the European Environment Agency [27] on collectors and WWTPs built by 31 December 2014, in the municipalities of the different EU countries. This information has been extended until December 2017 using the census of the Territorial Delegation of the Environment and Territorial Organization of the Junta de Andalucía in Jaén and the Provincial Council. Finding of the preliminary study are as follows.

a. The province of Jaén has 97 municipalities, 64 of which should have had a WWTP in place by 31 December 2005, as established in art. 4 of Directive 91/271/EEC; a requirement that has not been fulfilled.

b. A total of 39 urban centres in the province of Jaén that generate an estimated load of 2000 p.e. (population equivalent: organic biodegradable load that has a five-day biochemical oxygen demand $\left(\mathrm{BOD}_{5}\right)$ of 60 grams of oxygen per day) or more had built a WWTP by the end of 2017. Of these, six remain out of use, while 33 are in operation. Of these 33, a total of 23 are functioning properly (Table 1), in compliance with the requirements set out in Annex I of Directive 91/271/EEC; consequently, we can consider the composition of the treated wastewater in these WWTPs as homogeneous. In the province of Jaén, there is no more stringent regulation governing the quality of wastewater. These 23 WWTPs comprise the total population of the study.

c. Of the 23 that are functioning properly, data were available for 18.

d. There are also 23 population centres with a load of less than 2000 p.e. located in protected areas, according to the Department of Environment of the Junta de Andalucía, which have WWT facilities.

Table 1. Wastewater treatment plant (WWTP) situation in December 2017 for municipalities that generate a load of 2000 p.e. or more.

\begin{tabular}{ccc}
\hline WWTP Situation & Number & Percentage \\
\hline Without WWTP & 25 & $39.03 \%$ \\
Abandoned & 6 & $9.38 \%$ \\
Non-compliant operation & 10 & $15.63 \%$ \\
Compliant operation & 23 & $35.94 \%$ \\
Total & 64 & $100.00 \%$ \\
\hline
\end{tabular}

${ }^{1}$ Latest available information.

A survey was designed based on a prior, in-depth consultation with a group of seven experts, all of whom were WWTP managers. They explained that fixed costs are those that are incurred each year, regardless of the volume of water collected and treated by each WWTP in the fiscal year. All the concepts used in the questions were carefully explained to the respondents before carrying out the survey. The surveys were administered individually to the people in charge of managing the facilities or their chosen representative. The basic data of the technical data sheet of the empirical study are shown in the following tables.

Table 1 shows the WWTP situation in December 2017 for the municipalities of the province that generated a load equal to or greater than 2000 p.e. First and foremost, it is worth noting that in most cases the commitments in the field of wastewater management established by the EU standard are not met. In fact, only 23 of the WWTPs operate in accordance with the specifications established in Annex 1 of Directive 91/271/EEC: this group constitutes the study population. However, only 18 valid 
interviews were obtained from those plants. Of the total number of installations visited, ten apply a secondary treatment for prolonged aeration and eight use active sludge. In 2017, the facilities analysed achieved an average reduction of $82.50 \%$ in $\mathrm{BOD}_{5}, 88.29 \%$ in COD and $87.51 \%$ in suspended solids. Then, Table 2 contains the technical data of the empirical study, with a description of the different elements, and Table 3 refers to the WWTP capacity and number.

Table 2. Technical data of the empirical study.

\begin{tabular}{|c|c|c|}
\hline & Descriptive Elements & Description \\
\hline \multirow{6}{*}{ Population } & Sampling units & $\begin{array}{l}\text { WWTPs of the province of Jaén in operation in } 2017 \\
\text { in accordance with the ARU Directive }\end{array}$ \\
\hline & Total population & 23 WWTPs \\
\hline & Sampling elements & $\begin{array}{c}\text { Maximum Person responsible for the administration } \\
\text { of the WWTP or chosen representative }\end{array}$ \\
\hline & Scope & Province of Jaén \\
\hline & Temporary reference period & Year 2017 \\
\hline & Execution time & 1 March 2018 to 5 July 2018 \\
\hline \multirow{3}{*}{ Sampling } & Sample size & 23 surveys \\
\hline & Valid surveys & 18 surveys \\
\hline & Approximate sample error & $\begin{array}{c}11.01 \text { percent, for } p=q=0.5 \text { and a confidence level of } \\
95.5 \text { percent }\end{array}$ \\
\hline
\end{tabular}

Table 3. WWTP capacity and number.

\begin{tabular}{ccc}
\hline WWTP Capacity & Number & Percentage \\
\hline Less than 10,000 p.e. & 3 & $16.67 \%$ \\
Between 10,001 and 20,000 p.e. & 8 & $44.44 \%$ \\
Between 20,001 and 30,000 p.e. & 3 & $16.67 \%$ \\
Between 30,001 and 40,000 p.e. & 1 & $5.56 \%$ \\
Between 40,001 and 50,000 p.e. & 1 & $5.56 \%$ \\
More than 50,000 p.e. & 2 & $11.11 \%$ \\
Total & 18 & $100.00 \%$ \\
\hline
\end{tabular}

\subsection{Municipal WWT Rates in the Province of Jaén}

In Spain, in accordance with Law 8/1989, of 13 April, on Public Rates and Prices, and with Local Government Regulatory Law 7/1985, the sewage and WWT service comes under the jurisdiction of the municipality. A fee may be charged for the provision of these services, representing tax revenues for the local administration. These taxes are approved by the municipalities, meaning that the amount of the tax and how it is applied vary widely across the country. The taxable event is the provision of the sewage service and, where applicable, the treatment and purification of wastewater, in the absence of taxes directly linked to the WWT. The relevant taxpayers are individuals or companies, communities of homeowners, and other entities referred to in art. 33 of the General Tax Law, who request the service and/or benefit from it.

It should be underlined that the revenues collected through WWT rates are not based on the volume of water discharged. On the contrary, they depend on the number of connections to the municipal supply network and/or the volume of water billed to the user of the supply service, as established by the various municipal ordinances in force in 2017, published in the Official Gazette of the Province [24]. The analysis of the structure of ecotaxes levied on WWT in the province of Jaén allows us to identify three different types with varying impact on taxpayer decisions [28]. First, there are those that apply a fixed charge, regardless of the volume of water supplied to each account holder; this is the least common system and incompatible with the polluter pays principle. The second type entails a variable rate, depending on the amount of water billed; this system can be found in three of the 18 municipalities analysed. Finally, the predominant model consists of a fixed charge and a variable 
rate that depends on the amount of water billed to the account holder. In this option, the fixed charge can be a constant amount that is charged annually per account holder or, where appropriate, an amount that depends on the diameter of the water meter, as in six of the 18 examples considered. The rates applied also vary according to the type of account holder: lower for domestic use and public centres and higher for industry or business. In accordance with the above, it has been decided that the costs of the WWT service should be estimated using the volume of water billed to the account holder/taxpayer and not by the total amount of treated water. In the province, the total $\mathrm{m}^{3}$ of wastewater that eventually reaches the municipal WWTPs is, on average, 70\% higher than the volume of water billed. This is due to the fact that the water channelled to WWTPs includes domestic sewage; water discharged as a result of productive activity (commercial, industrial, energy, etc.); rainwater; water used for cleaning the streets; water supplied but not billed, due to the losses that take place in the supply system; and other sources, including water from small aquifers, springs and natural sources, which are abundant in some areas of Jaén [29].

\subsection{Empirical Study Procedure}

The survey consists of 21 sections, grouped into three categories. In the first group, the questions addressed general WWTP data: the year in which it began operations, cost of the facilities, volume of water treated, volume of water billed by the municipality on the basis of which the WWT rate is charged, the management system or the destination of the treated water. The other survey sections were designed taking into account $[7,8,16]$; especially the recommendations and standard practice of those responsible for the management of the WWTPs surveyed. The second section was designed to determine the fixed operational and running costs, independent of the volume of wastewater treated by the WWTP every year. This section includes information on the costs incurred for maintenance, electrical and electronic equipment, as well as measurement and control equipment. In addition, the following costs were counted; the fixed costs of the personnel working at the WWTP, the fixed charge for electricity and other fixed costs derived from administrative management, and services contracted from other companies for testing, cleaning, etc. Finally, the third section addresses issues related to the variable costs, depending on the volume of treated water. These include the cost per kilowatt of consumed energy, the cost of reagents used in the WWTP and the expenses derived from the transfer and treatment of waste and sludge generated in the installation, as well as a set of other variable expenses including, for example, the cost of diesel for any vehicles that may be used. The survey form is summarized in Table 4.

Table 4. Survey form.

\begin{tabular}{|c|c|}
\hline \multicolumn{2}{|c|}{ General Questions } \\
\hline Type of treatment & Management system of the WWTP \\
\hline Year of operation & Volume of water billed \\
\hline Funding entities & Volume of treated water \\
\hline Equivalent load & Destination of treated water \\
\hline \multicolumn{2}{|l|}{ Cost of operation, without VAT } \\
\hline Questions about Fixed Costs & Questions about Variable Costs \\
\hline Amount in $€$ & Amount in $€$ \\
\hline Facilities maintenance & Electricity \\
\hline Equipment maintenance & Reagent consumption \\
\hline Personnel & Disposal of hazardous waste \\
\hline Management (laboratory, private office) & Disposal of nonhazardous waste \\
\hline Services contracted from other companies & Sludge management \\
\hline Fixed charge for electricity connection & Other variable costs (diesel and others) \\
\hline
\end{tabular}




\subsection{Cost Analysis Method}

The economic analysis of the operational costs of the WWTPs of the province of Jaén is carried out for a normal functioning of the WWTP, with the design charges considered in the calculations. The accounting model followed associates expenses with a consumption of resources, including all costs and differentiating between those related to the operation and maintenance of the facilities and those related to capital or investment. To that end, equity accounting criteria are applied rather than budgetary accounting, which uses the measurement approach based on financial flow [30]. The first step is to estimate the average economic cost per $\mathrm{m}^{3}$ of treated wastewater, which can help inform the decision-making of the town councils of the province, who are responsible for the service.

The operating and maintenance costs comprise of (a) annual fixed costs, composed of maintenance and servicing expenses of the facilities; maintenance and servicing for electronic equipment, computers, measurement devices, vehicles, etc.; personnel expenses (gross wages and salaries); fixed charge for the electricity connection; and other fixed costs (services contracted from other companies such as testing, security, cleaning, administration, financial expenses, etc.); and (b) variable costs, comprising the cost of electricity ( $\mathrm{kW}$ consumed), the cost of diesel (if the WWTP has a vehicle), reagent consumption and waste disposal (hazardous and nonhazardous).

The investment costs are those that result from the depreciation of capital assets used in the WWT process, associated with the construction of public works, industrial buildings and electronic and computer equipment. In order to determine the fixed assets depreciation system, it has been taken into account that WWTPs in Spain are under municipal jurisdiction, managed directly or indirectly by the town councils. To estimate the depreciation costs of the facilities, the criteria applied are those established by the national legislation regulating municipal entities' accounting. The first of those are the provisions of Rule (8c) of Order HAP/1781/2013, of 20 September, approving the instruction of the standard local accounting model and Rule (9c) of Order HAP/1782/2013, of 20 September, approving the instruction of the simplified model of local accounting.

- Rule (8c) of the standard model stipulates that the Plenary of the Local Authority, at the proposal of the comptroller or body of the local entity responsible for the accounting function, should determine the criteria for the depreciation of the elements of fixed assets and, where appropriate, the revaluation model for the subsequent valuation of fixed assets.

- Rule (9c) of the simplified model stipulates that the Plenary of the Local Authority, at the proposal of the comptroller, should determine the criteria for the depreciation of the elements of the fixed assets.

Accordingly, the criteria to be used are those that each local authority deems appropriate, although they may refer to and base these on the Resolution of 14 December 1999, on the General Comptroller of the State Administration and the depreciation model in the private sphere contained in Law 27/2014, of 27 November, on corporation tax. In general, public goods have a long useful life, so the use of commercial tables is recommended to depreciate assets over the maximum permitted life [31].

The depreciation method applied to each one of the components of the WWTP determines the total amount for consumption of fixed capital included in the operating costs. Thus, considering that depreciation should be taken into account as it quantifies the consumption of resources, we applied the following criteria to calculate it.

1. Remaining life $=0$

2. The initial cost of the facilities is the value of the investment, divided between industrial building $(59.79 \%)$ and electrical and electronic equipment $(40.21 \%)$. The associated percentages are derived from the average share of total costs of these two concepts in ten analysed WWTP projects.

3. The straight-line depreciation method is applied to each type of asset. The maximum depreciation period for the industrial building is 68 years, according to the depreciation tables published by the Ministry of Finance and Public Administrations for 2017 [32]. 
4. The estimated useful life for electrical and electronic equipment is 10 years, according to the Ministry of Finance and Public Administrations of Spain for 2017, a value that has been used in other papers [25].

5. At the end of the useful life of the asset, the criterion of renewal accounting is followed as an alternative to depreciation. This entails assuming that the assets are maintained over time, even if the expenditure to maintain or repair the assets occurs in a specific financial year [30].

\section{Results}

\subsection{Revenues from WWT Rates}

The revenues collected by the different municipalities of the province of Jaén that have implemented ecotaxes to finance the WWT service are estimated from the amount per $\mathrm{m}^{3}$ paid by the account holder. To that end, we consider a four-person household with a consumption of 132 litres per person per day [33], equivalent to $15.84 \mathrm{~m}^{3}$ per month. When the calculation takes into account the diameter of the meter, a $15 \mathrm{~mm}$ gauge is chosen, considering a flow of 5.5 litres per inhabitant per hour or 22 litres per household per hour.

Figure 1 shows the amount charged for WWT $\left(€ / \mathrm{m}^{3}\right)$ in the different municipalities, revealing notable heterogeneity. In fact, a four-person household could pay very different amounts for the municipal WWT service depending on their place of residence. The estimated data present a high coefficient of variation, greater than $34 \%$, making the average value of $0.37 € / \mathrm{m}^{3}$ less representative. Eight municipalities have average values below this amount, and only two collect more than $0.5 € / \mathrm{m}^{3}$.

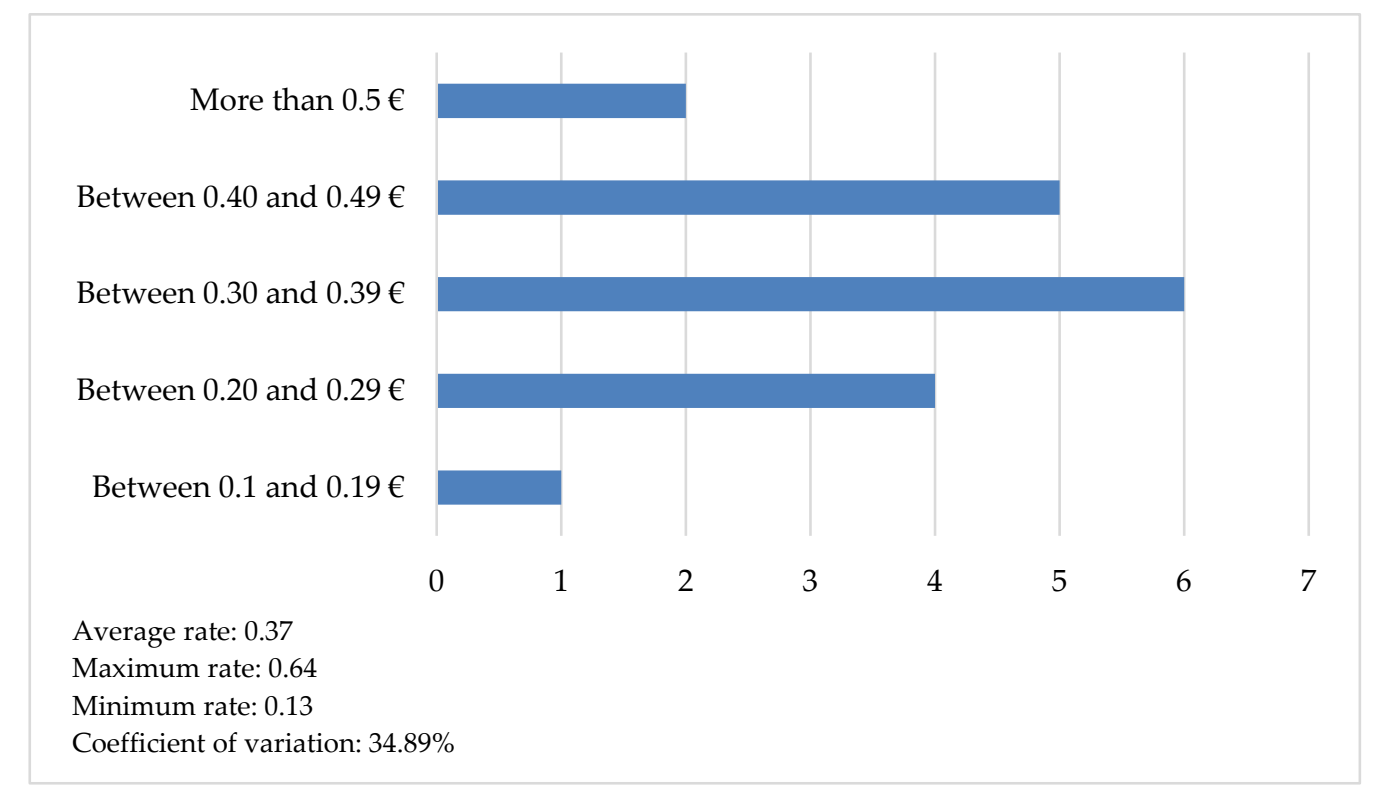

Figure 1. Number of municipalities and amount paid for WWT $\left(€ / \mathrm{m}^{3}\right)$ in the province of Jaén. Source: own elaboration from [24].

\subsection{Estimated Costs}

According to the WFD, the estimation of the costs of the WWT service should include the financial costs as well as the so-called environmental costs. The latter reflect the additional expense involved in restoring the status or potential of water bodies by rectifying the deterioration caused by the service, in which the degree of recovery is assessed. Bearing in mind that the water discharged by the WWTPs analysed in the empirical study meets the criteria established by Directive 91/271/EEC, environmental costs are not included in this estimation. 
Based on the information obtained from the empirical study carried out and the established criteria, the estimated average cost per $\mathrm{m}^{3}$ of treated water in the municipal WWT facilities of the province is $0.31 € / \mathrm{m}^{3}$, as shown in Table 5 . This value ranges between a minimum of 0.17 and a maximum of $0.53 € / \mathrm{m}^{3}$, depending on the type of installation, the size of the WWTP and even the age of the facilities. In the municipal WWTPs that have been operating for less than 10 years-22.22\% of the cases analysed-the costs attributable to the depreciation of electrical and electronic equipment are, in general, above average, representing $39.6 \%$ of total costs. On the other hand, in those facilities built prior to 2007, where the equipment is considered fully depreciated, the only fixed capital cost is linked to public works. It is worth noting that, not counting the exceptions due to specific events (unpredictable equipment breakages), those WWTPs that have been in operation for more than ten years register the highest annual maintenance and replacement costs for electrical and electronic equipment components.

Table 5. Cost in $€$ per $\mathrm{m}^{3}$ of treated water in the province of Jaén in 2017.

\begin{tabular}{cccc}
\hline & Average & Minimum & Maximum \\
\hline Fixed operating and maintenance costs & 0.17 & 0.09 & 0.19 \\
Variable operating and maintenance costs & 0.08 & 0.06 & 0.08 \\
Operating and maintenance costs & 0.25 & 0.14 & 0.27 \\
Depreciation & 0.06 & 0.03 & 0.26 \\
Total cost & 0.31 & 0.17 & 0.53 \\
Coefficient of variation & & $34.06 \%$ & \\
\hline
\end{tabular}

Figure 2 shows the share of the different items in the total operating and maintenance costs that the municipal WWT services face annually. As can be seen from the information in Table 6, together these represent more than $80 \%$ of the total average costs of this service.

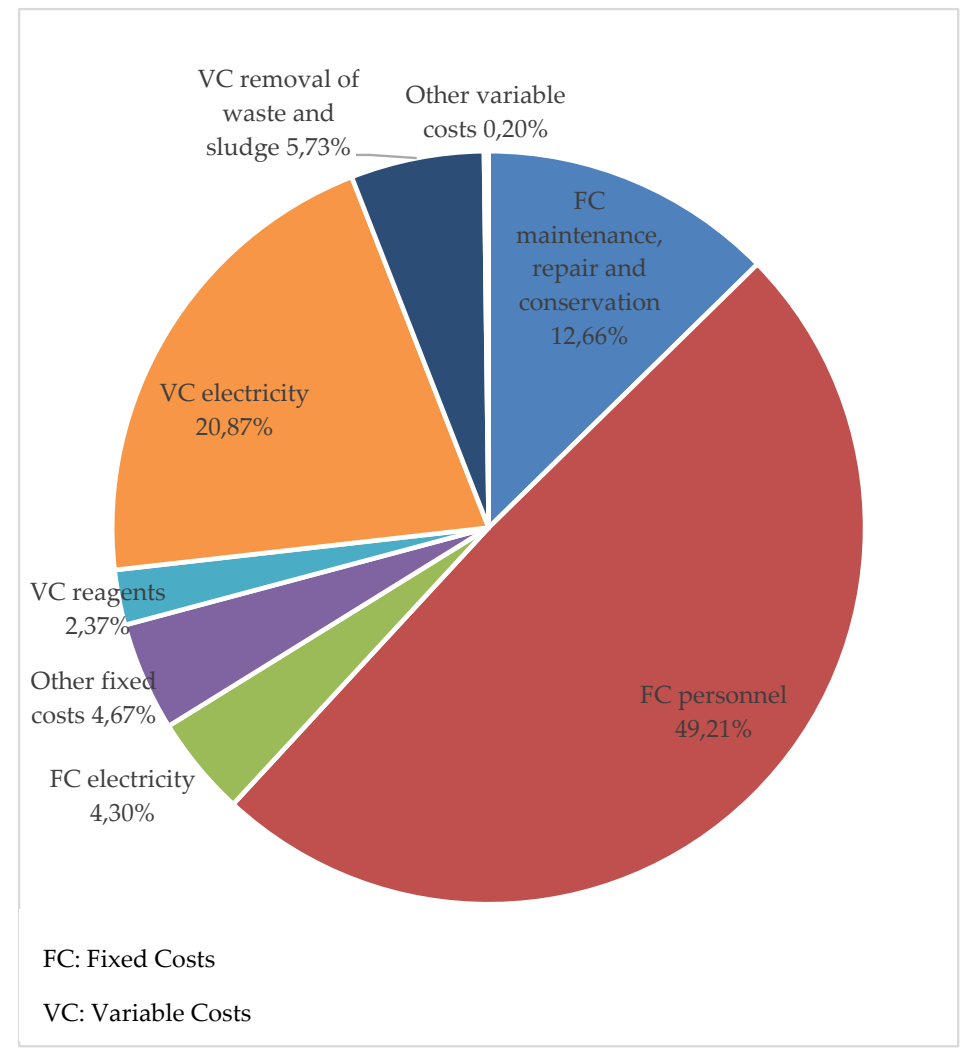

Figure 2. Structure of the average operation and maintenance costs per $\mathrm{m}^{3}$ of treated wastewater in the province of Jaén. 
Table 6. Cost in $€$ per $\mathrm{m}^{3}$ of billed water in the province of Jaén in 2017.

\begin{tabular}{cccc}
\hline & Average & Minimum & Maximum \\
\hline Fixed operating and maintenance costs & 0.23 & 0.15 & 0.31 \\
Variable operating and maintenance costs & 0.18 & 0.10 & 0.19 \\
Operating and maintenance costs & 0.41 & 0.25 & 0.50 \\
Depreciation & 0.10 & 0.06 & 0.38 \\
Total cost & 0.51 & 0.30 & 0.88 \\
Coefficient of variation & & $27.27 \%$ & \\
\hline
\end{tabular}

The gross wages and salaries paid to personnel accounts for the largest share, representing $49.21 \%$ of the total. The next largest is electricity consumption, which represents $25.17 \%$, including both the fixed charge for the connection and the variable cost per kilowatt consumed. On average, the energy bill of a WWTP in the province slightly exceeds $€ 75,000$ per year. However, whereas the smaller WWTPs with a capacity of 6910 p.e. registered an energy consumption in 2017 of $€ 23,500$, in the largest WWTPs of the province, the energy bill exceeds $€ 150,000$ per year. Altogether, the rest of the components account for $25.62 \%$ of the total, with the cost of maintenance, repair and servicing recording the highest relative value, followed by waste and sludge removal.

Table 6 shows the average cost per $\mathrm{m}^{3}$ billed, which is higher than the average cost per $\mathrm{m}^{3}$ treated; this is to be expected, given that the volume of treated water is much greater than the volume billed.

\subsection{Cost Recovery Index}

According to the polluter pays principle established by the WFD, the revenue collected by the municipalities through the WWT rates should finance the service costs [5,6,15-17]. The costs of WWT should be transferred to the water rates paid by citizens [15]. The information obtained from the empirical study carried out, in which we estimate the total operating cost of a WWTP per $\mathrm{m}^{3}$ of water billed, including running, maintenance and investment costs, confirms that in only three of the municipalities analysed does the income generated by taxes cover the total WWT costs. However, most of the WWTPs under study achieve a cost recovery index of more than $75 \%$ (in Table 7).

Table 7. Cost recovery index (CRI) per number of municipalities.

\begin{tabular}{ccc}
\hline & $\begin{array}{c}\text { Total Costs (Number of } \\
\text { Municipalities) }\end{array}$ & $\begin{array}{c}\text { Operating and Maintenance Costs } \\
\text { (Number of Municipalities) }\end{array}$ \\
\hline CRI $>100$ & 3 & 4 \\
$100>$ CRI $>75$ & 8 & 13 \\
$70>$ CRI $<50$ & 3 & 0 \\
CRI $<50$ & 4 & 1 \\
Total & 18 & 18 \\
CRI Average & 75 & 90 \\
Coefficient of Variation & 34.24 & 25.52 \\
\hline
\end{tabular}

The construction and start-up of the municipal WWTPs have been financed by transfers of public money from supraprovincial institutions, such as the regional government or the State, rather than by the municipalities. In addition, the water treatment fee that the regional government charges has a fixed purpose and should go towards constructing new buildings and renovating existing ones. Under this criterion, municipal tax revenues should only guarantee the financing of operating and maintenance expenses. In this case, there are four municipalities with a cost recovery rate above 100 , while $77.77 \%$ of municipalities collect insufficient revenues to cover the cost of operating and maintaining the facilities. This approach is inadequate from an economic point of view, as it suggests the real cost of the WWT service is being underestimated. Likewise, it is inappropriate from a legal standpoint, as art. 24.2 of the Law Governing Local Tax Offices stipulates that it is the municipalities that must guarantee the maintenance of the service [25]. 


\section{Discussion}

A homogeneous structure for ecotaxes on wastewater was not found in the analysed urban centres that collect such a tax. In some municipalities, an amount is charged per account holder, regardless of the volume of wastewater produced. Therefore, a two-member household pays the same as a business, a café or a warehouse where fruit is washed, even though they are responsible for widely differing volumes of wastewater and degrees of contamination. In other cases, the revenue collected is a function of the volume of water billed to each client. In most municipalities, however, the tax consists of a fixed charge plus a variable rate that is linked to the $\mathrm{m}^{3}$ recorded in the account holder's water meter. In no case, however, does the amount charged depend on the volume of wastewater and the pollution load. The taxes levied in the municipalities do not account for the effects on the ecological status of water bodies [34]. Given the varying structures of the taxes applied, the analysis confirms that a four-member household resident in the province of Jaén can pay very different amounts for the WWT service, depending on the municipality where they live. This gives rise to intraprovincial inequality between users of the WWT service, for both families and companies.

Adequate management of urban wastewater brings great benefits to society as a whole, both in terms of human health and the environment. Accordingly, there is an evident need to know the total costs of the urban WWT service. These can vary widely, as can be seen in the analysis carried out. The volume of water actually treated, the size of the plant, the type of equipment installed and the plant's management model are some of the factors that determine the total cost per $\mathrm{m}^{3}$ of water billed to the taxpayer. This cost can vary between $€ 0.30$ per $\mathrm{m}^{3}$ and $€ 0.88$ per $\mathrm{m}^{3}$ in the facilities of the province of Jaén that operate according to the criteria established by Directive 91/271/CEE. An appropriate system of information and cost quantification, designed according to economic criteria, will allow sound decisions to be made regarding the safe and long-term financing of WWTPs [35], helping to prevent improper functioning or plant closure, as has occurred in $41 \%$ of towns in the province of Jaén with a WWTP.

In the Guadalquivir river basin district, which includes $99 \%$ of the territory of the province of Jaén, an estimated cost recovery of $84.36 \%$ is estimated for the joint sewerage and WWT service [26]. According to the analysis carried out, most of the municipalities are unable to cover $80 \%$ of the costs required for the proper treatment of wastewater, and in some cases the cost recovery rate is less than $20 \%$. As a result, a substantial number of local governments are subsidizing part of the costs incurred for the provision of the municipal WWT service, which affects the balance of the municipal budgets.

The results obtained are in line with other studies $[6-8,25]$. Total cost recovery is often a critical problem that has yet to be resolved in many countries, especially in low-income regions, where these services are partially financed by government subsidies [35]. Very often, the revenue collected is insufficient, especially in times of crisis, which can lead to inadequate maintenance of the facilities, the deterioration of the systems and the degradation of the natural water environment.

\section{Conclusions}

Art. 4 of Directive 91/271/CEE obliges Member States to treat wastewater using secondary treatment or equivalent by no later than 31 December 2000 for agglomerations with a load of more than 15,000 p.e., and by no later than 31 December 2005 for wastewater discharged into freshwater or estuaries coming from agglomerations with a load equal to or greater than 2000 p.e. More than a decade later, this obligation is not being met in many EU municipalities, as is the case in the province of Jaén, in southern Europe. This situation means that the environmental objectives set out in art. 4 of the WFD are not being achieved. The discharge of untreated effluent into public water resources is a major problem that requires firm action on the part of the responsible institutions, which must act to ensure compliance with the regulation.

The adequate treatment of urban wastewater before being discharged requires resources to finance the process. The situation analysed in this study reveals the need for a thorough review of the mechanisms that ensure the full financing of this service, accounting for the total operating costs 
of the municipal WWTP. It also highlights inappropriate structures that should be avoided, such as the payment of a fee that is independent of the volume of wastewater discharged, or even the volume of water consumed and invoiced. It is not simply a question of the responsible authorities increasing their rates indiscriminately to achieve higher incomes and avoid a deficit. Reducing the volume of untreated wastewater and improving the quality of treated wastewater benefits society as a whole. As stated in Decision No. 1386/2013 EU of the European Parliament and of the Council on a General Union Environment Action Programme to 2020, in accordance with the EU's Sustainable Development Goals, measures must be adopted to protect the natural water environment [36]. To that end, it is essential to take advantage of the programmes financed by the European Structural and Investment Funds and, specifically, by the European Regional Development Fund, for which wastewater is a priority axis [37]. In addition, at the national level, extraordinary financing mechanisms can be proposed. For instance, additional resources could be gained by applying the principle of taxpaying capacity, which would allow higher rates to be charged to high-income service users [38] and through specific social responsibility campaigns, encouraging contributions from companies and citizens. Indeed, the collaboration of all citizens and companies is essential to the implementation of such initiatives, which require a combination of promotional campaigns, incentives and regulation.

The general public must be aware that it is not simply about complying with European legislation on the protection of water resources in order to avoid fines for discharging polluting waters, whether imposed by national or supranational institutions (specifically, in the latter case, by the European Commission, as occurred in 2018 in Spain). Above all, there is an urgent need to establish objectives, design strategies and implement actions aimed at improving the financial conditions of WWT services, thereby helping to protect the environment.

Author Contributions: Conceptualization and Methodology, E.M.P.; Formal Analysis, I.M.R.S.; Investigation and Resources E.M.P and L.G.V.; Data Curation, L.G.V.; Writing-Original Draft Preparation, E.M.P.; Writing一Review and Editing, E.M.P. and L.G.V.; Supervision, E.M.P. and I.M.R.S.

Funding: This research was funded by the Instituto de Estudios Giennenses of the Diputación Provincial of Jaén, in the framework of a research project on the economic analysis of the treatment management system of urban wastewater in the province of Jaén and the assessment of its capacity to obtain regenerated water.

Conflicts of Interest: The authors declare no conflicts of interest.

\section{References}

1. Cheng, S. Heavy metal pollution in China: origin, pattern and control. Environ.Sci. Pollut. Res. 2003, 10, $192-198$. [CrossRef]

2. Kou, S.; Vincent, G.; Gonzalez, E.; Pitre, F.E.; Labrecque, M.; Brereton, N.J. the response of a 16s ribosomal RNA Gene fragment amplified community to Lead, Zinc, and Copper pollution in a Shanghai field trial. Front. Microbiol. 2018, 9, 366. [CrossRef] [PubMed]

3. Gallego-Valero, L.; Moral-Pajares, E.; Román-Sánchez, I.M. The tax burden on wastewater and the protection of water ecosystems in EU countries. Sustainability 2018, 10, 212. [CrossRef]

4. Rosenstock, M. Environmental Taxation within the European Union. Cyprus Econ. Policy Rev. 2014, 8, 113-123.

5. Román-Sánchez, I.M.; Carra, I.; Sánchez-Pérez, J.A. Promoting environmental technology using sanitary tax: the case of agro-food industrial wastewater in Spain. Environ. Eng. Manage. J. 2014, 13, 961-969.

6. Gallego-Valero, L.; Moral-Pajares, E.; Román-Sánchez, I.M.; Sánchez-Pérez, J.A. Analysis of environmental taxes to finance wastewater treatment in Spain: An opportunity for regeneration? Water 2018, 10, 226. [CrossRef]

7. World Health Organization. UN-Water Global Analysis and Assessment of Sanitation and Drinking-Water (GLAAS) 2014 Report: Investing in Water and Sanitation: Increasing Access, Reducing Inequalities; WHO: Geneva, Switzerland, 2014.

8. Jouravlev, A.; Lentini, E.; Yurquina, A.; Fernández, D. Contabilidad Regulatoria, Sustentabilidad Financiera y Gestión Mancomunada: Temas Relevantes en Servicios de Agua y Saneamiento; Comisión Económica para América Latina y el Caribe (CEPAL): Santiago, Chile, 2009. 
9. Molinos-Senante, M.; Hernández-Sancho, F.; Sala-Garrido, R. Economic feasibility study for wastewater treatment: A cost-benefit analysis. Sci. Total Environ. 2010, 408, 4396-4402. [CrossRef] [PubMed]

10. Theregowda, R.; Hsieh, M.K.; Walker, M.E.; Landis, A.E.; Abbasian, J.; Vidic, R.; Dzombak, D.A. Life cycle costs to treat secondary municipal wastewater for reuse in cooling systems. J. Water Reuse Desalin. 2013, 3, $224-238$. [CrossRef]

11. Oh, K.S.; Poh, P.E.; Chong, M.N.; Gouwanda, D.; Lam, W.H.; Chee, C.Y. Optimizing the in-line ozone injection and delivery strategy in a multistage pilot-scale greywater treatment system: System validation and cost-benefit analysis. J. Environ. Chem. Eng. 2015, 3, 1146-1151. [CrossRef]

12. De la Cruz, N.; Esquius, L.; Grandjean, D.; Magnet, A.; Tungler, A.; De Alencastro, L.F.; Pulgarín, C. Degradation of emergent contaminants by UV, UV/H2O2 and neutral photo-Fenton at pilot scale in a domestic wastewater treatment plant. Water Res. 2013, 47, 5836-5845. [CrossRef] [PubMed]

13. Guerrini, A.; Romano, G.; Leardini, C.; Martini, M. Measuring the efficiency of wastewater services through data envelopment analysis. Water Sci. Technol. 2015, 71, 1845-1851. [CrossRef] [PubMed]

14. Castellet, L.; Molinos-Senante, M. Efficiency assessment of wastewater treatment plants: A data envelopment analysis approach integrating technical, economic, and environmental issues. J. Environ. Manag. 2016, 167, 160-166. [CrossRef] [PubMed]

15. Gómez, T.; Gémar, G.; Molinos-Senante, M.; Sala-Garrido, R.; Caballero, R. Assessing the efficiency of wastewater treatment plants: A double-bootstrap approach. J. Cleaner Prod. 2017, 164, 315-324. [CrossRef]

16. Molinos-Senante, M.; Hernández-Sancho, F.; Sala-Garrido, R. Cost-benefit analysis of water-reuse projects for environmental purposes: A case study for Spanish wastewater treatment plants. J. Environ. Manag. 2011, 92, 3091-3097. [CrossRef] [PubMed]

17. Prieto-Rodríguez, L.; Oller, I.; Klamerth, N.; Agüera, A.; Rodríguez, E.M.; Malato, S. Application of solar AOPs and ozonation for elimination of micropollutants in municipal wastewater treatment plant effluents. Water Res. 2013, 47, 1521-1528. [CrossRef] [PubMed]

18. Organisation for Economic Co-operation and Development. Pricing of Water Services; Organisation for Economic Co-operation and Development (OECD): Paris, France, 1987.

19. Organisation for Economic Co-operation and Development. Household Water Pricing in OCDE Countries, París: Environment Policy Committee; Organisation for Economic Co-operation and Development (OECD): Paris, France, 1999.

20. Organisation for Economic Co-operation and Development. Environmental Performance Reviews (1st Cycle): Conclusions \& Recommendations 32 Countries (1993-2000); Organisation for Economic Co-operation and Development (OECD): Paris, France, 2001.

21. Gawel, E. Article 9 Water Framework Directive: Do We Really Need to Calculate Environmental and Resource Costs? Helmholtz-Zentrum für Umweltforschung (UFZ): Leipzig, Germany, 2014.

22. Ortíz, E.J. La experiencia de Holanda y Alemania en el uso de cargos por vertimientos de aguas residuales como instrumento para el control de la contaminación hídrica. Elementos para decidir los parámetros a ser tenidos en consideración. Economía y Desarrollo 2005, 4, 55-87.

23. Perman, R.; Ma, Y.; McGilvray, J.; Common, M. Natural Resource and Environmental Economics; Pearson Education Limited: Glasgow, Scotland, 2003.

24. Boletín Oficial de la Provincia de Jaén. Ordenanzas sobre las tasas de depuración. Available online: https:/ / bop.dipujaen.es/ (accessed on 15 December 2017).

25. Barberá, R.; Costa, A.; Alegre, A. Los costes de los servicios urbanos del agua. Un análisis necesario para el establecimiento y control de tarifas. Hacienda Pública Española 2008, 186, 123-155.

26. Confederación Hidrográfica del Guadalquivir. Plan Hidrológico de la Demarcación Hidrográfica del Guadalquivir (2015-2021). Anejo n 9. Recuperación de costes de los servicios del agua; Ministerio de Agricultura: Alimentación y Medio Ambiente, 2015.

27. EEA. Data and Maps. Available online: https://www.eea.europa.eu/es (accessed on 15 December 2017).

28. Stiglitz, J.E. La economía del sector público (Vol. 24). Antoni Bosch Editor: Barcelona, Spain, 2003.

29. Instituto Tecnológico Geominero de España. Atlas Hidrológico de la Provincia de Jaén. Available online: http:/ /aguas.igme.es/igme/publica/libro76/lib76.htm (accessed on 15 December 2017).

30. Pelejero, L. La amortización del inmovilizado en contabilidad pública. Auditoría pública: Revista de los Organos Autónomos de Control Externo 1997, 10, 47-52. 
31. Diputación Provincial de Toledo. Available online: http://www.diputoledo.es/global/10/ver_pdf/25139 (accessed on 15 December 2017).

32. Agencia Tributaria. Impuesto Sobre Sociedades. Tabla de Coeficientes de Amortización Lineal. Available online: https: / / www.agenciatributaria.es / (accessed on 15 December 2017).

33. Instituto Nacional de Estadística. Indicadores sobre el agua. Available online: http://www.ine.es/jaxi/ Tabla.htm?path=/t26/p069/p03/serie/10/\&file=01001.px\&L=0 (accessed on 15 December 2017).

34. Berbel, J.; Martin-Ortega, J.; Mesa, P. A cost-effectiveness analysis of water-saving measures for the water framework directive: the case of the Guadalquivir River Basin in Southern Spain. Water Resour. Manag. 2011, 25, 623-640. [CrossRef]

35. United Nations Water. Informe Mundial De Las Naciones Unidas Sobre El Desarrollo De Los Recursos Hídricos, 2017: Aguas Residuales: el Recurso no Explotado; UNESCO: Paris, France, 2017.

36. European Parliament and European Union Council. Decisión n. 1386/2013/UE relativa al Programa General de Acción de la Unión en materia de Medio Ambiente hasta 2020 "Vivir bien, respetando los límites de nuestro planeta"; European Parliament and Council: Brussels, Belgium, 2013.

37. European Parliament and European Union Council. Reglamento n. 1301/2013 de 17 de diciembre de 2013 sobre el Fondo Europeo de Desarrollo Regional y sobre disposiciones específicas relativas al objetivo de inversión en crecimiento y empleo y por el que se deroga el Reglamento (CE) n. 1080/2006; European Parliament and Council: Brussels, Belgium, 2013.

38. García, M.A. Fijación de precios para el servicio municipal de suministro de agua: un ejercicio de análisis de bienestar. Hacienda Pública Española 2005, 172, 119-144.

(C) 2019 by the authors. Licensee MDPI, Basel, Switzerland. This article is an open access article distributed under the terms and conditions of the Creative Commons Attribution (CC BY) license (http:// creativecommons.org/licenses/by/4.0/). 